\title{
Feedback and uptake in videoconferences for online intercultural exchange
}

\section{Ruiling Feng ${ }^{1}$, Xiuhong Shi ${ }^{2}$, Songlian $\mathrm{Hu}^{3}$, and Yong $\mathrm{Yu}^{4}$}

Abstract

Tncidental Focus on Form (FonF) refers to the treatment of linguistic elements incidentally arising in a communicative setting during a meaning-focused activity. _ Videoconferencing for Online Intercultural Exchange (OIE) projects represents a typical meaning-focused communication activity but incidental FonF in group-based OIE projects is underexplored. The present study investigated the longitudinal changes of feedback types and factors related to successful uptake in Zoom-based videoconferences during a five-week OIE project. Chinese students and US students participated in weekly Zoom videoconferences to collect intercultural student ethnography data for their group projects with English as the exchange language. The videoconferences were recorded, transcribed, coded, and subsequently analysed quantitatively. Results returned that recast, clarification request, and translation were more frequently used but their frequencies did not significantly fluctuate throughout the OIE project, while metalinguistic feedback, elicitation, and explicit corrective feedback were less commonly used but their frequencies of use varied significantly. Repair provider (self-repair vs. other repair) and English proficiency were significantly associated with Chinese students' successful uptake. The findings have implications for incorporating OIE and similar virtual exchange models into language teaching and learning.

\footnotetext{
1. Tianjin Normal University, China; ruilingfeng@zoho.com.cn; https://orcid.org/0000-0002-2482-3146

2. Tianjin Normal University, China; samanthasxh@126.com; https://orcid.org/0000-0002-8783-4758

3. Tianjin Normal University, China; 974842885@qq.com; https://orcid.org/0000-0002-6341-0504

4. State University of New York at Plattsburgh, United States; yyu001@plattsburgh.edu; https://orcid.org/0000-0002-8533-6966
}

How to cite this article: Feng, R., Shi, X., Hu, S., \& Yu, Y. (2021). Feedback and uptake in videoconferences for online intercultural exchange. Journal of Virtual Exchange, 4 (SI-IVEC2020), 28-46. https://doi.org/10.21827/jve.4.37159 
Keywords: online intercultural exchange; English for academic purposes; feedback; uptake; focus on form.

\section{Introduction}

Incidental FonF has been defined as the treatment of linguistic elements incidentally arising in a communicative setting during a meaning-focused activity (e.g. Doughty \& Williams, 1998; Ellis, 2001). Feedback and uptake are two related terms in a Focus on Form Episode (FFE) and also essential concepts in language learning. FonF can be further classified into two types: reactive and preemptive. The reactive type refers to an FFE where feedback follows an error, while the preemptive type is initiated with a query without the presence of an error (Ellis, Basturkmen, \& Loewen, 2001). Allwright (1984) defined uptake as all that learners obtain from language classes. Lyster and Ranta (1997) claimed that uptake is a reactive move that immediately follows the teacher's feedback (any response regardless of its quality). Uptake, based on quality, has two categories, namely successful uptake and unsuccessful uptake. Successful uptake means that the learners successfully incorporate the linguistic information of feedback into their response (Egi, 2010; Ellis et al., 2001). Successful uptake helps learners to benefit the most from feedback (Shekary \& Tahririan, 2006).

Studies on FonF have gathered evidence for its occurrence and factors of successful uptake (e.g. Chen \& Eslami, 2013; Loewen, 2005), but research gaps exist. First, most studies to date have examined FonF in communication in classroom settings or laboratory settings (e.g. Ellis, 2001; Mackey, Oliver, \& Leeman, 2003; Sheen, 2004, 2006). Second, research on FonF in Computer-Mediated Communication (CMC) largely examined data from text-based chats (e.g. Eslami \& Kung, 2016; Kung \& Eslami, 2015; Kwon \& Lee, 2011; Tudini, 2012), while video chats as an oral-visual modality are underrepresented in FonF research (e.g. Akiyama, 2017; Wang, 2006). However, videoconferencing can provide intensive exposure to the target language (Kato, Spring, \& Mori, 2016; Lim \& Pyun, 2016; Spring, Kato, \& Mori, 2019). With the use of videoconferencing technologies like Zoom and Skype in an international virtual exchange project, feedback and uptake might have different attributes from those occurring in face-to-face communication or text-based chats. Also, video-based communication investigated in previous research is largely on dyadic interaction (e.g. Saito \& Akiyama, 2017) rather than group chat, and FonF in group chat has been suggested to be different from FonF in dyadic interaction (Tudini, 2012). Furthermore, previous studies largely analysed cross-sectional data in FonF-related research rather than longitudinal data (e.g. Ellis et al., 2001). Last, when investigating factors related to successful uptake, researchers mostly take characteristics of FFEs as independent variables predicting successful uptake (e.g. Loewen, 2005), yet characteristics of language learners 
(such as language proficiency), which might be significant predictors, are largely excluded from the regression model. Therefore, a thorough exploration of FonF in group-based CMC has not yet been addressed.

Correspondingly, the present study explored the changes in feedback and uptake in students' verbal production during a five-week Native Speakers-Non-Native Speakers (NSs-NNSs) videoconferencing-based OIE project, and we also examined what factors were related to successful uptake. The videoconferences in this study were all group talk, which represents a different interaction mechanism from dyadic talk in aspects such as turn-taking, topic transition, and opportunities to speak out (Tudini, 2012). We included English proficiency as one of the predictors in the regression model to predict successful uptake. This study sheds light on feedback and uptake in an underexplored modality and extends FonF research by examining the longitudinal changes throughout the OIE project.

To sum up, scarce is research that examines Fonf behaviours in group-based videoconferences within an OIE project. The purpose of this research was to investigate whether there were any changes in American university students' feedback and Chinese English learners' uptake during their weekly OIE videoconferences and what factors were related to Chinese students' successful uptake. The present study addressed the following research questions (RQs).

RQ1: What types of feedback, if any, were provided by US students during the five-week OIE project? Did the number of feedback moves change according to feedback types during the exchange?

RQ2: What factors were related to Chinese students' successful uptake?

\section{Literature review}

\subsection{Feedback in incidental FonF}

Incidental FonF refers to attention to language forms during meaning-oriented communication (Kwon \& Lee, 2011). It can be reactive or preemptive. Reactive FonF includes errors and corrective feedback (Ellis, 2001), while preemptive FonF means that the interaction trajectory shifts to language form through one interlocutor's query about a language form in the absence of an error (Egi, 2010; Sheen, 2004). Feedback in FonF is conducive to improved language accuracy by reducing errors in later production. Peer feedback can help language learners notice the gap 
between the target language and their interlanguage, and such noticing could be facilitative in language learning (Crystal, 2001; Tudini, 2012).

Feedback can be categorised into recast, clarification requests, metalinguistic feedback, elicitation, and repetition (Choi \& Li, 2012). Recast is implicit reformulation or expansion of an ill-formed usage (Egi, 2010). Its implicit nature might mean that learners fail to notice the gaps in their interlanguage (Kwon \& Lee, 2011). Clarification requests hold back correct forms and elicit reformulation or repetition from the students (Fernández-García \& Martínez-Arbelaiz, 2014; Panova \& Lyster, 2002). This feedback type often results in pushed output in the form of other-initiated self-repair (Clavel-Arroitia, 2019; Tudini, 2012). Metalinguistic feedback involves comments, information, or questions related to the well-formedness of an utterance without explicitly providing the correct answer (Lyster \& Ranta, 1997). Elicitation does not provide linguistic information but prompts the learner to self-correct (Shekary \& Tahririan, 2006). Explicit corrective feedback features explicit signals to the students that there is an error in the previous utterance (Panova \& Lyster, 2002). Explicit correction is generally unfavoured in oral communication (Clavel-Arroitia, 2019; Lyster, 2005) because of its face-threatening feature. Recasts are the most commonly used feedback type in communication (Ellis et al., 2001), particularly in written synchronous computer-assisted communication (Akbar, 2017), owing to their time-saving and unobtrusive nature (Akiyama, 2017). Lyster (1998) found that most recasts were followed by acknowledgement instead of successful uptake, but Panova and Lyster (2002) reported that recasts and explicit corrective feedback may be followed by successful uptake because these feedback types offer target-like forms. Also, clarification requests, translation, and elicitation may be more likely followed by modified output because the learners are pushed to do so (Egi, 2010; Shirani, 2019).

Different frequencies of feedback types in meaning-focused communication are related to their different face-threatening natures and speakers' needs for face-saving. Tudini (2012) noticed that native speakers tended to sacrifice truthfulness for face-supporting behaviours to mitigate embarrassment. This could explain the popularity of recast and disapproval of explicit correction in meaning-oriented communication (Varonis \& Gass, 1985).

\subsection{Uptake and related factors in incidental FonF}

Uptake refers to the response immediately after the feedback (Lyster \& Ranta, 1997). Based on uptake quality in reactive FonF, uptake can be categorised into repair and need-repair in terms of

whether learners successfully correct their errors after corrective feedback (Kwon \& Lee, 2011). Repair means learners correct their errors in only one turn, and need-repair means that they fail 
to do so. Repair can be self- or peer repair. Self-repair means the error is corrected by whoever commits it while peer repair indicates that the error is corrected by others.

To better categorise uptake quality, Ellis, Basturkmen, and Loewen (2001, 2002, 2012) introduced the concept of successful and unsuccessful uptake to describe learners' responses not only to reactive feedback but also to preemptive feedback. Studies have consistently found that learners' uptake with the production of a more target-like modified output contributes to L2 development, and successful uptake is the strongest indicator of interlanguage development (Loewen, 2005; McDonough, 2004, 2005; Nobuyoshi \& Ellis, 1993; Shekary \& Tahririan, 2006). Thus, successful uptake supports interlanguage development more than the mere presence of uptake (Egi, 2010; Loewen, 2005; Shekary \& Tahririan, 2006; Williams, 2001).

Characteristics of feedback and uptake are often included as independent variables in regression models to predict successful uptake (e.g. Loewen, 2005, 2010; Shekary \& Tahririan, 2006), but characteristics of the English as a Foreign Language (EFL) learners are largely ignored in the regression model.

\subsection{OIE}

OIE is an approach to engaging students in interaction and collaboration with partners from geographically and culturally different places (O’Dowd, 2007), aiming to develop language skills and intercultural communication skills (Belz, 2003; O’Dowd, 2018). It represents a class-to-class language-mediated intercultural partnership in which language is regarded as "a resource for doing things” instead of the predominant focus of learning (O’Dowd \& Lewis, 2016, p. ix).

In second language acquisition studies, OIE and similar virtual exchange models such as e-tandem have been shown to help language learning in various ways (O’Dowd, 2011). For example, Saito and Akiyama (2017) reported that the Japanese EFL learners improved their comprehensibility, fluency, and lexicogrammar, with the feedback provided by their trained US partners in weekly dyadic video chats. Tudini (2012) found that native speakers and non-native speakers engaged in incidental FonF which helped the non-native speakers improve linguistic accuracy in later production. The modality affects FonF behaviour, as real-time video chats trigger more loss of face for language learners than text-based chats (Van der Zwaard \& Bannink, 2014, 2016). Most previous studies, however, focus on dyadic communication (e.g. Akiyama, 2017; Kato et al., 2016; Spring et al., 2019), while group-based video chat is underexplored. 


\section{Research design}

\subsection{Participants}

A total of 19 Chinese EFL learners (19-20 years old) at a university in China and 14 English native speakers (21-23 years old) at a university in the US participated in the study. All the Chinese students were sophomores majoring in Japanese, Russian, or electric engineering, and all the US students were junior students majoring in teacher education with different subject areas. Students on both sides were divided into seven international groups; each group had two to three Chinese and two US students. They all gave consent to have their Zoom videoconference recordings analysed for this study. Their personal information has been kept confidential.

\subsection{Instructional setting}

The five-week OIE project in this study was a collaboration between an education course at the US university and an English for General Academic Purposes course at the Chinese university. One of the objectives of the education course was to help students better understand intercultural differences and culturally responsive teaching, while one of the objectives of the English for General Academic Purposes course was to improve students' English production skills and intercultural communication competence. The OIE project was developed in alignment with these two objectives. A shared syllabus with a topic list was provided by the co-teaching professors. All the topics (e.g. housing, food, sports) were closely related to the real-life and personal experience of college students so that all the participants had something to ask or share. Every international group communicated as learning peers, not as English experts and English learners. However, the Chinese students inevitably noticed their English disadvantages and expected to learn idiomatic English from their US partners. The US students were not instructed to be language experts, though they were reminded of the language learner status of their Chinese peers and advised to be more patient when communication breakdowns occurred.

The OIE project was divided into three parts, namely ice-breaker, ethnography interview, and wrapup. The first week was for an ice-breaker. Both sides in every international group attended a Zoom meeting, familiarised each other with demographic information, hobbies, typical daily activities, etc. and decided on the date and time for the following Zoom videoconferences. Weeks 2 to 4 were for semi-structured interviews. Students of every international group asked their international peers prepared questions and further probing questions. Every speaker was both an interviewer (data collector) and interviewee (data provider). Students collected data about the assigned topic for each week for the final product. The interview approach was consistent with the intercultural student 
ethnography discussed by O'Dowd (2006). Week 5 was for wrap-up when students summed up their previous communication and showed gratitude to each other. The presentation, the final product of the OIE project, asked students to synthesise their interview data and look for any patterns and themes showing up from their international partners' answers. The following week, students did their OIE presentations by local groups instead of international groups; therefore, this week was not counted in this study. The communication was meaning-focused and information-based and neither side was instructed to pay special attention to language forms; therefore, FFEs were expected to incidentally and naturally arise during the video chats. Activities like the interview, information synthesis, intercultural communication, and presentation are all important parts of academic English literacy.

Groups instead of dyads were adopted for several reasons. First, based on our informal interviews with students before the collaboration began, students (especially the Chinese EFL learners) would feel lower language and cultural anxiety because they could help each other with both content and language. Also, the weekly video talk could be better secured even when one student could not participate. Furthermore, group collaboration might resemble tasks in professional settings more than dyadic collaboration. Lastly, 'small groups' of four to five students accorded with stronger social presence and interpersonal dynamics than dyads (Dörnyei \& Murphey, 2003), though dyads can also feature high social presence under certain circumstances (Satar, 2013, 2020). Students had to compete harder for the floor in group talk than in dyadic talk (Tudini, 2012).

\subsection{Data collection and analysis}

Every OIE group was required to submit their Zoom videoconference recording every week. The Chinese students were required to transcribe the recordings to the utmost of their efforts. Twenty-nine videos were collected in total. Three groups submitted all five videos as required; two groups submitted four videos; two groups submitted three videos. The videos were carefully watched and transcribed (verbatim). Additionally, the Chinese students' English proficiency data were collected. Before the OIE project, they took a test with items drawn from a commercial examination database system developed by Shanghai Foreign Language Education Press and delivered and assessed by the faculty team of the English for General Academic Purposes course in the Chinese university. The test resembled College English Test - Band 4 in structure; the latter is a test of non-English majors' English proficiency and is extensively used in Mainland China (Guo \& Sun, 2014). We used the test result as a measurement of Chinese students' English proficiency. Besides, the Chinese instructor kept a teaching journal recording the OIE-related discussions in weekly classes. 
FFE in the present study refers to the treatment of linguistic forms as it arises incidentally in a meaning-focused communication (Doughty \& Williams, 1998; Ellis, 2001; Ellis et al., 2001, 2002, 2012; Loewen, 2005; Long, 1991). An FFE could be instigated by Chinese students' linguistic errors that received feedback from their US partners (reactive FFE) or by Chinese students' queries of some linguistic items during the ongoing videoconference (preemptive FFE).

Once the FFEs were identified, they were coded according to a range of characteristics adapted from the coding framework in Loewen's (2005, 2010) and Panova and Lyster's (2002) research. Table 1 shows the specific coding framework in detail. Feedback was categorised into recast, clarification request, metalinguistic feedback, elicitation, translation, and explicit correction. Linguistic focus had three categories: phonological, lexical, and grammatical focus. Instigation included preemptive FFE and reactive FFE. Repair move was classified into self-repair and other repair. Uptake quality was a binary variable, including successful uptake and unsuccessful uptake. Though Chinese students sometimes provided feedback to their Chinese peers, we did not include such FFEs in this study, because according to students' reports in classes, at times these FFEs occurred in the videoconference room whereas they occurred outside of the room on other occasions.

Table 1. Feedback and uptake coding framework

\begin{tabular}{|c|c|c|c|}
\hline Characteristics & Definitions & Categories & Examples \\
\hline \multirow[t]{6}{*}{ Feedback type } & $\begin{array}{l}\text { Implicit reformulation or } \\
\text { expansion of an ill-formed } \\
\text { item in an unobtrusive way }\end{array}$ & Recast & $\begin{array}{l}\text { C1: But the Opium makes } \\
\text { China change a lot. } \\
\text { U1: Bec you said it changed } \\
\text { China a lot. It did in the past. }\end{array}$ \\
\hline & $\begin{array}{l}\text { Elicitation reformulation } \\
\text { or repetition }\end{array}$ & Clarification request & $\begin{array}{l}\text { C2: So I think we should } \\
\text { dialectical view. } \\
\text { U2: Dialectical view? } \\
\text { C2: No, critical. }\end{array}$ \\
\hline & $\begin{array}{l}\text { Comments, information, or } \\
\text { questions related to the well- } \\
\text { formedness of the student } \\
\text { utterance without explicitly } \\
\text { providing the correct answer }\end{array}$ & Metalinguistic feedback & $\begin{array}{l}\text { U2: Yeah, critical is a better } \\
\text { choice than dialectical. }\end{array}$ \\
\hline & $\begin{array}{l}\text { Prompting the learner } \\
\text { to self-correct }\end{array}$ & Elicitation & $\begin{array}{l}\text { U1: Because you said it changed } \\
\text { China a lot. It did in the past. } \\
\text { C1: It made Chinese } \\
\text { people addicted... }\end{array}$ \\
\hline & $\begin{array}{l}\text { A move after learners' } \\
\text { unsolicited uses of L1 }\end{array}$ & Translation & C3: 辩证法... \\
\hline & $\begin{array}{l}\text { Explicit signals to the student } \\
\text { that there is an error in } \\
\text { the previous utterance }\end{array}$ & Explicit corrective feedback & $\begin{array}{l}\text { U8: 'should' is a strong } \\
\text { word. It's not proper when } \\
\text { you propose something. }\end{array}$ \\
\hline
\end{tabular}




\begin{tabular}{|c|c|c|c|}
\hline \multirow[t]{3}{*}{ Linguistic focus } & Dealing with phonological errors & Phonological & $\begin{array}{l}\text { U10: What do you mean? } \\
\text { C12: Oh, I mean /prr/ pressure, } \\
\text { not/per/ pressure. }\end{array}$ \\
\hline & Dealing with lexical errors & Lexical & $\begin{array}{l}\text { See the example for } \\
\text { clarification request }\end{array}$ \\
\hline & Dealing with grammatical errors & Grammatical & See the example for recast \\
\hline \multirow[t]{2}{*}{ Instigation } & $\begin{array}{l}\text { Instigated by a query } \\
\text { about a language item }\end{array}$ & Preemptive & $\begin{array}{l}\text { C16: Can I say you are rich? } \\
\text { U12: Haha, I don't think so. A } \\
\text { basement is common here. }\end{array}$ \\
\hline & $\begin{array}{l}\text { Instigated by a linguistic error } \\
\text { made by a Chinese student }\end{array}$ & Reactive & See the example for recast \\
\hline \multirow[t]{2}{*}{ Repair provider } & $\begin{array}{l}\text { Repair made by the student } \\
\text { who committed the error }\end{array}$ & Self-repair & $\begin{array}{l}\text { See the example for } \\
\text { clarification request }\end{array}$ \\
\hline & Repair provided by a US student & Peer repair & See the example for recast \\
\hline \multirow[t]{2}{*}{ Uptake quality } & $\begin{array}{l}\text { EFL learners incorporated } \\
\text { linguistic information into } \\
\text { subsequent production }\end{array}$ & Successful & See the example for recast \\
\hline & $\begin{array}{l}\text { EFL learners did not incorporate } \\
\text { linguistic information into } \\
\text { subsequent production }\end{array}$ & Unsuccessful & See the example for preemptive \\
\hline
\end{tabular}

Two authors identified the FFEs together, then discussed the feedback and uptake characteristics and coded them independently. A third author was then invited to discuss disagreements with the authors who carried out the coding. Final decisions were made with $100 \%$ agreement of all three coders. Raw frequency of each characteristic of feedback and uptake was standardised as frequency/hour (length of videoconference) for comparability across the weeks. FFE frequencies were calculated per group per week. The significance level for all tests was set at 0.05. For all statistical analyses, we used the software SPSS 20.

To answer RQ1 (the changes of feedback), Friedman tests, which are the non-parametric counterpart of within-subject ANOVA, were performed to investigate weekly changes in the number of feedback and uptake instances during the OIE project. The Friedman tests were conducted because distributions of feedback and uptake characteristics violated the normality assumption (MacFarland \& Yates, 2016). Before the Friedman tests, the missing values for the group(s) that had not submitted recordings were substituted by the mean value of the frequency of all related groups that week.

To answer RQ2 (factors related to successful uptake), a logistic regression test (for predicting a binary outcome variable) was conducted. In the case of data for the present study, logistic regression can help to determine what factors could predict successful uptake. Table 2 details the binary coding scheme for categorical dependent and independent variables and shows the values assigned to each 
category. For easier interpretation, feedback type was transformed into a dummy variable elicit which equals one when the US students tried to draw out from their Chinese partners a language form or information about a language form and zero when the US students gave information about a language form by recast, metalinguistic feedback, or explicit corrective feedback (Loewen, 2005). Linguistic focus featured a categorical variable and was transformed into two dummy variables, namely phonological (equal to one when the linguistic focus was at the phonological level, and zero otherwise) and lexical (equal to one when the linguistic focus was at the lexical level, and zero otherwise), while the grammatical level was the reference category (coded as zero) as the comparison object. Instigation was transformed into a dummy variable preemptive (equal to one when an FFE was preemptive, and zero when an FFE was reactive). Repair move was also recoded into a dummy variable peer_repair (equal to one when the corrective form was provided by a peer, and zero when by oneself). Uptake quality followed the same recoding procedure, succ_uptake (equal to one when the uptake was successful and zero otherwise). Logistic regression analysis with SPSS returns results

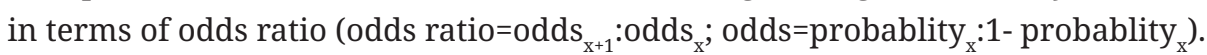

\section{Table 2. Binary coding scheme for logistic regression}

\begin{tabular}{|l|l|l|}
\hline Variables & Values & $\mathbf{0}$ \\
\cline { 2 - 3 } & $\mathbf{1}$ & Providing form-related information explicitly \\
\hline Elicit & $\begin{array}{l}\text { Drawing out form-related information } \\
\text { from EFL learners }\end{array}$ & FFE on other linguistic levels \\
\hline phonological & FFE at the phonological level & FFE on other linguistic levels \\
\hline Lexical & FFE at the lexical level & $\begin{array}{l}\text { FFE initiated by an error made } \\
\text { by the EFL learners }\end{array}$ \\
\hline preemptive & $\begin{array}{l}\text { FFE initiated by queries from the } \\
\text { EFL learners without errors }\end{array}$ & $\begin{array}{l}\text { Repair provided by the error } \\
\text { maker or query raiser }\end{array}$ \\
\hline peer_repair & Repair provided by peers & Unsuccessful uptake \\
\hline succ_uptake & Successful uptake & \\
\hline
\end{tabular}

\section{Results and discussion}

\subsection{Changes in the frequency of US students' feedback}

As shown in Table 3, the frequency of FFEs by students from the US was quite low in the video chats, corroborating the findings by van der Zwaard and Bannink (2016). Friedman test results did not indicate a consistent FFE pattern across the six feedback types. Three feedback types did not show significant differences throughout the five-week OIE project, namely recast, clarification request, and 
translation, while the other three types revealed significant differences, i.e. they were employed in significantly different amounts across the weeks. Those feedback types with no significant changes, however, were more frequently used than the three feedback types with significant changes. Recast, clarification request, and translation feature implicit, embedded feedback strategies; less face-threatening to the speaker of the problematic utterance. They are also less disruptive than metalinguistic feedback, elicitation, and explicit corrective feedback, which might bring EFL learners' errors to the surface (Tudini, 2012).

Table 3. Frequencies of US students' feedback moves across five weeks (standard deviation is reported in parenthesis)

\begin{tabular}{|c|c|c|c|c|c|c|}
\hline & Week 1 & Week 2 & Week 3 & Week 4 & Week 5 & $\mathbf{P}$ \\
\hline Recast & \begin{tabular}{|l}
0.75 \\
$(0.69)$
\end{tabular} & \begin{tabular}{|l}
0.25 \\
$(0.42)$
\end{tabular} & \begin{tabular}{|l|}
0.30 \\
$(0.40)$
\end{tabular} & \begin{tabular}{|l|}
0.33 \\
$(0.60)$
\end{tabular} & \begin{tabular}{|l|}
0.42 \\
$(0.83)$
\end{tabular} & 0.203 \\
\hline Clarification request & \begin{tabular}{|l}
0.33 \\
$(0.60)$
\end{tabular} & \begin{tabular}{|l}
0.33 \\
$(0.60)$
\end{tabular} & \begin{tabular}{|l|}
0.20 \\
$(0.35)$
\end{tabular} & \begin{tabular}{|l|}
0.17 \\
$(0.53)$
\end{tabular} & \begin{tabular}{|l|}
0.17 \\
$(0.36)$
\end{tabular} & 0.589 \\
\hline Metalinguistic feedback & $\begin{array}{l}0 \\
(0)\end{array}$ & \begin{tabular}{|l}
0 \\
$(0)$
\end{tabular} & $\begin{array}{l}1 \\
(1.52)\end{array}$ & \begin{tabular}{|l}
0.08 \\
$(0.27)$
\end{tabular} & \begin{tabular}{|l}
0 \\
$(0)$
\end{tabular} & 0.000 \\
\hline Elicitation & \begin{tabular}{|l}
0.08 \\
$(0.27)$
\end{tabular} & $\begin{array}{l}0 \\
(0)\end{array}$ & $\begin{array}{l}0 \\
(0)\end{array}$ & \begin{tabular}{|l}
0.08 \\
$(0.28)$
\end{tabular} & $\begin{array}{l}0 \\
(0)\end{array}$ & 0.044 \\
\hline Translation & $\begin{array}{l}0.79 \\
(2.225)\end{array}$ & $\begin{array}{l}0 \\
(0)\end{array}$ & $\begin{array}{l}0.07 \\
(0.267)\end{array}$ & $\begin{array}{l}0.07 \\
(0.267)\end{array}$ & $\begin{array}{l}0.07 \\
(0.267)\end{array}$ & 0.406 \\
\hline Explicit corrective feedback & $\begin{array}{l}0 \\
(0)\end{array}$ & $\begin{array}{l}0 \\
(0)\end{array}$ & \begin{tabular}{|l}
0.10 \\
$(0.26)$
\end{tabular} & \begin{tabular}{|l}
0.08 \\
$(0.27)$
\end{tabular} & $\begin{array}{l}0 \\
(0)\end{array}$ & 0.002 \\
\hline
\end{tabular}

Recast was the most dominant feedback type by the US students in the present study. Many previous studies also find that interlocutors in online communication prefer recast because of its implicit, polite, and unobtrusive nature (Shekary \& Tahririan, 2006; Tudini, 2012), but its implicitness and ambiguity may reduce its visibility as corrective feedback and thus entail a low uptake rate (Kwon \& Lee, 2011; Lyster, 1998; Sheen, 2004). Although no significant fluctuations in the number of recasts were observed across five weeks, they were used the most in the first videoconference, which might be due to unfamiliarity among the students of both sides and with the videoconferencing system.

Clarification request was the second most commonly used feedback type by the US students. It demonstrated no significant change across the weeks, but a relatively equal distribution through the OIE project. Although we did not code error types, our observations of the videoconference recordings and engagement with the data indicated that most of the clarification requests were likely due to communication breakdowns caused by pronunciation errors or inappropriate word choices (see relevant illustrative examples in Table 1). To continue the communication, repetition 
or reformulation of ill-formed or inappropriate utterances was necessary (Panova \& Lyster, 2002), corroborating the findings in Clavel-Arroitia's (2019) and Tudini's (2012) studies on online communication.

The amount of translation as an FFE did not show significant difference throughout the OIE project, but it was adopted predominantly in the first videoconference when the Chinese students were not accustomed to communicating 100\% in English, and thus they resorted to Chinese occasionally. Since the second videoconference, they rarely showed unsolicited use of their native language. EFL learners demonstrated less use of their native language when they communicated with people of a different native language than with people of the same native language as reported by Ozdener and Satar (2008). In this sense, OIE videoconference represents an L2-rich environment (Smartt \& Scudder, 2004).

The amount of metalinguistic feedback offered by US students changed significantly during the OIE project, but the significant difference was gained only in two pairwise comparisons, namely between the second videoconference and the third one, and the third one and the fourth one. According to the Chinese instructor, the third videoconference was the most relaxing one, as students on both sides had already been relatively accustomed to the Zoom videoconference and communication style of their international peers, but probably they did not yet feel pressed to prepare for their OIE presentation. Therefore, Chinese students could be more aware of the English expert status of their US partners and not feel too embarrassed to ask language-related questions. When the Chinese students took initiative to ask questions related to language form, arguably, the US students might be less worried about being face-threatening when taking an English expert role. Therefore, there was more metalinguistic feedback in the middle of the OIE project. Still, metalinguistic feedback shifted the communication from topical talk to pedagogical talk (Tudini, 2012). Pedagogical communication was not a central feature of the OIE project in this study, similar to the findings by Akbar (2017) on CMC.

The frequency of elicitation and explicit corrective feedback in US students' FFEs also changed significantly across five weeks, but their frequencies were very low throughout the OIE project. Both types are somehow face-threatening and interfere with ongoing communication (Sheen, 2004; Tudini, 2012), especially in videoconferences where virtual co-presence and cross-cultural communication required additional care of face-saving than text-based chat (Lamy \& Hampel, 2007). This dovetailed the finding by Akiyama (2017) that students in synchronous, video-based communication preferred unobtrusive feedback like recast over the explicit correction.

The relatively small number of feedback moves might be related to various factors. First and foremost, the OIE videoconference of this study was conducted for completing group projects, 
and therefore predominantly meaning-oriented. Focus on language form did not conform to the orientation toward meaning and thus only occurred occasionally, mainly when the gap between the EFL learners' interlanguage and the target language might cause a communication breakdown (Loewen, 2005). Second, group talk often featured multiple conversation threads and quick turn switching among interlocutors (Tudini, 2012), and thus time and opportunity were both more limited for feedback and uptake with modified output than that in dyadic chat.

\subsection{Factors related to Chinese students' successful uptake}

The logistic regression model was statistically significant, $\chi^{2}(7, n=65)=31.26(p<.001)$. The model explains $51.4 \%$ (Nagelkerke $\mathrm{R}^{2}$ ) of the variance in successful uptake. The Chinese students successfully uptook $42 \%$ of all the language forms in the 65 FFEs. This percentage was lower than successful uptake rate (60\%) reported in text-based online chat (Sotillo, 2010), but higher than that (30\%) reported in in-person face-to-face NS-NNS and NNS-NNS interaction (Mackey et al., 2003). A likely explanation for this is that video chat is more time-constrained than text-based chat (which features extra processing time with longer acceptable pauses between turns) and hence allowing less time for uptake. There were no significant differences in the likelihood between feedback types, between linguistic levels, and between instigation types, but significant differences in the likelihood were found, relating to repair provider and Chinese students' English proficiency (Table 4).

Table 4. Factors related to successful uptake $(n=65)$ (standard deviation in parenthesis)

\begin{tabular}{|l|l|l|l|l|}
\hline & B & $\operatorname{Exp}($ B) & Wald & P \\
\hline Elicit & $1.13(1.37)$ & 3.04 & 3.79 & 0.417 \\
\hline phonologicala & $-1.22(1.29)$ & 0.30 & 0.89 & 0.345 \\
\hline lexicala & $-1.465(1.28)$ & 0.23 & 1.32 & 0.252 \\
\hline Preemptive & $0.31(1.29)$ & 1.37 & 0.06 & 0.810 \\
\hline peer_repair & $3.58(1.35)$ & 35.78 & 7.06 & 0.008 \\
\hline Proficiency & $-0.14(.05)$ & 0.87 & 7.00 & 0.008 \\
\hline
\end{tabular}

Notes: a. The omitted category is the grammatical level.

A main effect was found for repair provider $(B=3.58, S E=1.35$, Wald=7.06, $\operatorname{Exp}(\mathrm{B})=35.78, p=.008)$, and for peer repair versus self-repair. The result indicates that when all other factors were controlled, the predicated odds of successful uptake when a Chinese students' language gap was filled by their US peers were 35.78 times the odds when the language gap was filled by the Chinese student him/herself. This might be caused by EFL learners' potentially limited competence of self-repair in synchronous video chats, while the repair move provided by the US peers might be more easily 
accepted with perceived better repair quality and immediacy. When an error was repaired by the US students, possibly the Chinese EFL learners treasured such language learning opportunities and actively incorporated the other-repairs into their subsequent utterance. This result contradicts Tudini's (2012) findings that self-repair is more likely to result in successful uptake.

A main effect was also found for English proficiency $(B=-.14, S E=.05$, Wald $=7.00, \operatorname{Exp}(B)=0.87$, $p=.008)$. Holding other variables constant, with one more point in English proficiency score $(x+1)$, the predicated odds of successful uptake decreased to 0.87 times the odds of the original score $(x)$. A more detailed examination of the videoconference recordings indicated that the Chinese EFL learners of higher proficiency tended to show acknowledgement (e.g. "Thank you for pointing out”), apology (e.g. "Sorry for the mistake”), or proceeded with the topical talk trajectory rather than incorporating the feedback into subsequent responses, consistent with Tudini's (2012) findings. This may sound counter-intuitive, but EFL learners of lower proficiency cared more about linguistic accuracy (Loewen \& Erlam, 2006), and showed higher awareness of the language value of OIE than the learners with higher language levels. The Chinese students of higher English proficiency might emphasise interpersonal affiliation and keep the trajectory more communicative rather than pedagogical, while the students of lower proficiency paid more attention to acquiring correct or more appropriate language forms to improve their interlanguage, as was similarly argued by Tudini (2012). As more than half of all the feedback moves (58\%) was not successfully uptaken in the videoconferences, Chinese students need to improve their apperception of the feedback from their native-speaker peers.

\section{Conclusions and implications}

During the five-week NS-NNS videoconferences, the number of observed feedback instances for three out of six feedback types (metalinguistic feedback, elicitation, and explicit corrective feedback) changed significantly. Though the number of observed instances of recast, clarification request, and translation did not change significantly over five weeks, they were more frequently used than the three feedback types with significant changes. Repair provider (self-repair vs. peer repair) was related to uptake quality (successful uptake vs. unsuccessful uptake), with peer repair predicting a higher likelihood of successful uptake. English proficiency was negatively associated with uptake quality. Other factors, including feedback type, linguistic level, and instigation were not significant predictors of successful uptake. OIE videoconferencing represents meaning-oriented communication where form-focused feedback concerning ill-formed language could be considered face-threatening and interfering. FFEs in this study occurred incidentally and resulted in a moderate level of successful uptake. 
The research results have implications for incorporating OIE and similar virtual exchange models into language teaching and learning. Since NS-NNS videoconferences for the OIE project only focused on form incidentally, English teachers who integrate an OIE element into their teaching might consider adapting the videoconference recordings as teaching materials, to better guide EFL learners as suggested by Spring et al. (2019). Meanwhile, the co-teaching instructors can set a minimum length of the weekly videoconference and require participation by all students (Spring et al., 2019), so that they could be further encouraged to conduct more in-depth and extensive discussions. Naturally, EFL learners can benefit from greater exposure to English. Last, OIE videoconferences provide a production-oriented (Wen, 2016) language learning environment for Chinese English learners. For such online international learning experiences to be more effective, EFL learners can prepare for the videoconference better, for example, by creating questions to ask their international peers and possible answers to these questions from their perspective.

This study has several limitations. First, the small sample of participants, relatively short duration of the longitudinal study, and consequently small number of FFEs might influence the significance of quantitative data analysis. Future research can recruit more participants and include a longer OIE project and accordingly a larger sample of FFEs. Another limitation of this study is that data analysis did not include paralinguistic and non-verbal features like tones, stress, facial expressions, and body gestures. Therefore, some feedback and uptake instances indicated by such features might have been excluded in the analysis. Arguably, we are particularly interested in successful uptake which is not affected by the paralinguistic and non-verbal features. Nevertheless, future research can include these features to draw a more detailed picture of the FFEs in NS-NNS videoconferences. Besides, this study is descriptive without a control group and tests of language learning. Future research can adopt a (quasi) experimental design and tailor-made tests based on the language items in the FFEs, to draw causal relationships between OIE and language learning, and then we will have hard evidence of language learning as a product of OIE.

\section{Ethics statement and acknowledgements}

This study has been reviewed and approved by the Ethics Committee of Foreign Language College, Tianjin Normal University.

This work was supported by the Tianjin Philosophy and Social Science Planning Grant "International Collaboration Community of Tertiary-level English Teaching-Learning-Research in 'Internet +' era” (Grant number: TJWW16-018). 


\section{References}

Akbar, F. S. (2017). Corrective feedback in written synchronous and asynchronous computer-mediated communication. Applied Linguistics \& TESOL, 17(2), 9-27.

Akiyama, Y. (2017). Learner beliefs and corrective feedback in telecollaboration: a longitudinal investigation. System, 64, 58-73

Allwright, R. (1984). Why don’t learners learn what teachers teach?-The interaction hypothesis. In D. Singleton \& D. Little (Eds), Language learning in formal and informal contexts (pp. 3-18). IRAAL.

Belz, J. (2003). Linguistic perspectives on the development of intercultural competence in telecollaboration. Language Learning and Technology, 7(2), 68-99.

Chen, W., \& Eslami, Z. (2013). Focus on form in live chats. Educational Technology \& Society, 16(1), 147-158.

Choi, S., \& Li, S. (2012). Corrective feedback and learner uptake in a child ESOL classroom. RELC Journal, 43(3), 331-351.

Clavel-Arroitia, B. (2019). Analysis of telecollaborative exchanges among secondary education students: communication strategies and negotiation of meaning. Porta Linguarum, 31, 97-116.

Crystal, D. (2001). Language and the internet. Cambridge University Press.

Dörnyei, Z., \& Murphey, T. (2003). Group dynamics in the language classroom. Cambridge University Press.

Doughty, C., \& Williams, J. (1998). Pedagogical choices in focus on form. In C. Doughty \& J. Williams (Eds), Focus on form in classroom second language acquisition (pp. 197-261). Cambridge: Cambridge University Press.

Egi, T. (2010). Uptake, modified output, and learner perceptions of recasts learner responses as language awareness. The Modern Language Journal, 94, 1-21.

Ellis, R. (2001). Introduction: investigating form-focused instruction. Language Learning, 51(Suppl. 1), 1-46.

Ellis, R., Basturkmen, H., \& Loewen, S. (2001). Learner uptake in communicative ESL lessons. Language Learning, 51(2), 281-318.

Ellis, R., Basturkmen, H., \& Loewen, S. (2002). Doing focus-on-form. System, 30(4), 419-432.

Ellis, R., Basturkmen, H., \& Loewen, S. (2012). Preemptive focus on form in the ESL classroom. TESOL Quarterly, 35(3), 407-432.

Eslami, Z. R., \& Kung, W. T. (2016). Focus-on-form and EFL learners' language development in synchronous computermediated communication: task-based interactions. The Language Learning Journal, 4, 401-407.

Fernández-García, M., \& Martínez-Arbelaiz, A. (2014). Native speaker-non-native speaker study abroad conversations: do they provide feedback and opportunities for pushed output? System, 42(1), 93-104.

Guo, Q., \& Sun, W. (2014). Economic returns to English proficiency for college graduates in Mainland China. China Economic Review, 30, 290-300.

Kato, F., Spring, R., \& Mori, C. (2016). Mutually beneficial foreign language learning: creating meaningful interactions through video synchronous computer-mediated communication. Foreign Language Annals, 49(2), 355-366.

Kung, W. T., \& Eslami, Z. R. (2015) Learners of different language proficiency levels and incidental focus on form in synchronous text-based discussion. International Journal of Computer-Assisted Language Learning and Teaching, 5(3), 42-59. 
Kwon, H., \& Lee, C. H. (2011). Learner uptake of feedback in text-based synchronous computer mediated communication (SCMC). Multimedia-Assisted Language Learning, 14(2), 211-234.

Lamy, M., \& Hampel, R. (2007). Online communication in language learning and teaching. Pilgrave Macmillan.

Lim, B., \& Pyun, D. O. (2016). Korean foreign language learning: videoconferencing with native speakers. In C. Wang \& L. Winstead (Eds), Handbook of research on foreign language education in the digital age (pp. 253-276). IGI Global. https://doi.org/10.4018/978-1-5225-0177-0.ch012

Loewen, S. (2005). Incidental focus on form and second language learning. Studies in Second Language Acquisition, 27(3), 361-386.

Loewen, S. (2010). Uptake in incidental focus on form in meaning-focused ESL lessons. Language Learning, 54(1), 153-188.

Loewen, S., \& Erlam, R. (2006). Corrective feedback in the chatroom: an experimental study. Computer Assisted Language Learning, 19(1), 1-14.

Long, M. H. (1991). Focus on form: a design feature in language teaching methodology. In K. Ginsberg, R. de Bot \& C. Kramsch (Eds), Foreign language research in cross-cultural perspective (pp. 39-52). John Benjamins.

Lyster, R. (1998). Negotiation of form, recasts, and explicit correction in relation to error types and learner repair in immersion. McGill University.

Lyster, R. (2005). Negotiation of form, recasts, and explicit correction in relation to error types and learner repair in immersion classrooms. Language Learning, 48(2), 183-218.

Lyster, R., \& Ranta, L. (1997). Corrective feedback and learner uptake: negotiation of form in communicative classrooms. Studies in Second Language Acquisition, 19, 37-66.

MacFarland, T. W., \& Yates, J. M. (2016). Introduction to nonparametric statistics for the biological sciences using $R$. Springer.

Mackey, A., Oliver, R., \& Leeman, J. (2003). Interactional input and the incorporation of feedback: an exploration of NSNNS and NNS-NNS adult and child dyads. Language Learning, 53(1), 35-66.

McDonough, K. (2004). Learner-learner interaction during pair and small group activities in a Thai EFL context. System, 32(2), 207-224.

McDonough, K. (2005). Identifying the impact of negative feedback and learners' responses on ESL question development. Studies in Second Language Acquisition, 27(1), 79-103.

Nobuyoshi, J., \& Ellis, R. (1993). Focused communication tasks and second language acquisition. ELT Journal, 47(3), 203-210.

O'Dowd, R. (2006). The use of videoconferencing and e-mail as mediators of intercultural student ethnography. In J. Belz \& S. L. Thorne (Eds), Internet-mediated intercultural foreign language education (pp. 86-120). Thomson Heinle.

O’Dowd, R. (2011). Online foreign language interaction: moving from the periphery to the core of foreign language education? Language Teaching, 44(3), 368-380.

O’Dowd, R. (2007). (Ed.). Online intercultural exchange: an introduction for foreign language teachers. Multilingual Matters.

O’Dowd, R. (2018). From telecollaboration to virtual exchange: state-of-the-art and the role of UNICollaboration in moving forward. Journal of Virtual Exchange, 1, 1-23. 
O’Dowd, R., \& Lewis, T. (2016). (Eds). Online intercultural exchange: policy, pedagogy, practice. Routledge.

Ozdener, N., \& Satar, H. M. (2008). Computer-mediated communication in foreign language education: use of target language and learner perceptions. Turkish Online Journal of Distance Education, 9(2). https://dergipark.org.tr/en/ download/article-file/156270

Panova, I., \& Lyster, R. (2002). Patterns of corrective feedback and uptake in an adult ESL classroom. TESOL Quarterly, 36(4), 573-595.

Saito, K., \& Akiyama, Y. (2017). Video-based interaction, negotiation for comprehensibility, and second language speech learning: a longitudinal study. Language Learning, 67(1), 43-74.

Satar, H. M. (2013) Multimodal language learner interactions via desktop videoconferencing within a framework of social presence: Gaze. ReCALL, 25(1), 122-142.

Satar, H. M. (2020). L1 for social presence in videoconferencing: a social semiotic account. Language Learning and Technology, 24(1), 129-153.

Sheen, Y. (2004). Corrective feedback and learner uptake in communicative classrooms across instructional settings. Language Teaching Research, 3, 263-300.

Sheen, Y. (2006). Exploring the relationship between characteristics of recasts and learner uptake. Language Teaching Research, 10(4), 361-392.

Shekary, M., \& Tahririan, M. H. (2006). Negotiation of meaning and noticing in text-based online chat. Modern Language Journal, 90(4), 557-573.

Shirani, R. (2019). Patterns of uptake and repair following recasts and prompts in an EFL context: does feedback explicitness play a role? Studies in Second Language Learning and Teaching, 9(4), 607-631.

Smartt, J. T., \& Scudder, R. R. (2004). Immersion study abroad in Mexico: using repair behaviors to assess proficiency changes. Foreign Language Annals, 37(4), 592-599.

Sotillo, S. (2010). Quality and type of corrective feedback, noticing, and learner uptake in synchronous computermediated text-based and voice chats. In M. Putz \& L. Sicola (Eds), Cognitive processing and second language acquisition: inside the learner's mind (pp. 351-370). John Benjamins.

Spring, R., Kato, F., \& Mori, C. (2019). Factors associated with improvement in oral fluency when using video-synchronous mediated communication with native speakers. Foreign Language Annals, 52(1), 87-100.

Tudini, V. (2012). Online second language acquisition. Continuum.

Van der Zwaard, R., \& Bannink, A. (2014). Video call or chat? Negotiation of meaning and issues of face in telecollaboration. System, 44, 137-148.

Van der Zwaard, R., \& Bannink, A. (2016). Nonoccurrence of negotiation of meaning in task-based synchronous computer-mediated communication. The Modern Language Journal, 100(3), 625-640.

Varonis, E. M., \& Gass, S. (1985). Non-native/non-native conversations: a model for negotiation of meaning. Applied Linguistics, 6(1), 71-90.

Wang, Y. (2006). Negotiation of meaning in desktop videoconferencing-supported distance language learning. ReCALL, 18(1), 122-146. 
Wen, Q. (2016). The production-oriented approach to teaching university students English in China. Language Teaching, 51(4), 1-15.

Williams, J. (2001). The effectiveness of spontaneous attention to form. System, 29(3), 325-340. 


\section{Virtual Exchange?}

Published by University of Groningen Press | UGP, a not-for-profit press

Groningen, The Netherlands | UGP@rug.nl

(C) 2021 UNICollaboration (collective work)

(C) 2021 by Authors (individual work)

Journal of Virtual Exchange 2021

Special issue edited by Carine Ullom and Müge Satar

Publication date: 2021/10/15

Journal of Virtual Exchange (JVE) is an online, open-access, peer-reviewed journal aimed at practitioners and researchers in the field known variously as virtual exchange, telecollaboration, or online intercultural exchange. It is the official journal of UNICollaboration (https://www.UNICollaboration.org/), the international academic organisation dedicated to supporting and promoting telecollaboration and virtual exchange in higher-level education.

Rights. The whole volume is published under the Attribution-NonCommercial-NoDerivatives 4.0 International licence (CC BY-NCND 4.0); individual articles may have a different licence. Under the CC BY-NC-ND licence, the volume is freely available online for anybody to read, download, copy, and redistribute provided that the author(s), editorial team, and publisher are properly cited. Commercial use and derivative works are, however, not permitted.

Disclaimer. University of Groningen Press does not take any responsibility for the content of the pages written by the authors of this article. The authors have recognised that the work described was not published before, or that it was not under consideration for publication elsewhere. While the information in this article is believed to be true and accurate on the date of its going to press, neither UniCollaboration nor University of Groningen Press can accept any legal responsibility for any errors or omissions. Additionally, the publisher makes no warranty, expressed or implied, with respect to the material contained herein. While University of Groningen Press is committed to publishing works of integrity, the words are the authors' alone.

Trademark notice. Product or corporate names may be trademarks or registered trademarks, and are used only for identification and explanation without intent to infringe.

Copyrighted material. Every effort has been made by the editorial team to trace copyright holders and to obtain their permission for the use of copyrighted material in this article. In the event of errors or omissions, please notify the publisher of any corrections that will need to by incorporated in future editions of this article.

Typeset by Research-publishing.net (https://research-publishing.net)

Noto fonts are open source. All Noto fonts are published under the SIL Open Font License, Version 1.1. Noto is a trademark of Google Inc. (https://www.google.com/get/noto/).

ISSN: 2647-4832 (online only)

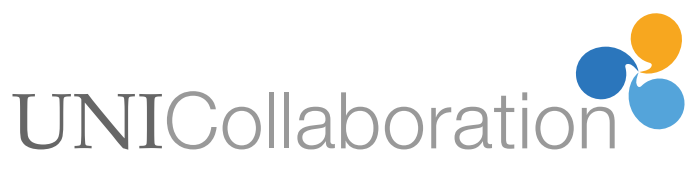

